\title{
РОЛЬ ЕНДОТЕЛІАЛЬНОЇ ДИСФУНКЦІЇ В РОЗВИТКУ АРТЕРІАЛЬНОЇ ГІПЕРТЕНЗІЇ У ХВОРИХ НА АНКІЛОЗИВНИЙ СПОНДИЛОАРТРИТ
}

\author{
ДВНЗ «Тернопільський державний медичний університет імені І.Я. Горбачевського МОЗ України», \\ м. Тернопіль, Україна
}

\begin{abstract}
Мета: встановити роль ендотеліальної диссункції в розвитку артеріальної гіпертензії у хворих на анкілозивний спондилоартрит.

Матеріали і методи. Обстежено 110 пацієнтів з анкілозивним спондилоартритом, яким проводили оцінку стану ендотелію. До моменту включення в дослідження всі пацієнти отримували базисну антигіпертензивну терапію, котра не змінювалась під час обстеження.

Результати. Встановлено, що практично кожен третій пацієнт хворів на артеріальну гіпертензію, порушення фрункції ендотелію виявлено у 71,8 \% хворих. Достатньо велика когорта обстежених демонструвала знижений рівень ЛПВщ і підвищений рівень ЛПНЩ. Поряд із тим, виявлено суттєві відмінності за показниками активності захворювання (СРБ, ШОЕ, BASDAI) та функціонального статусу (BASFI) у пацієнтів з артеріальною гіпертензією та без.

Висновки. Можна припустити, що саме диссрунцція ендотелію, котра виникає на фроні системного запального синдрому, ймовірно, $€$ основною причиною розвитку артеріальної гіпертензії у пацієнтів 3 анкілозивним спондилоартритом, адже відмінностей за іншими класичними фракторами ССР, окрім дисліпідемій, виявлено не було.
\end{abstract}

КЛЮЧОВІ СЛОВА: анкілозивний спондилоартрит; артеріальна гіпертензія; ендотеліальна дисфункція.

Анкілозивний спондилоартрит (AC) - хронічне системне запальне захворювання 3 переважним ураженням осьового скелета (крижово-клубових, міжхребцевих, реберно-хребтових зчленувань) $[1,9]$, що належить до групи серонегативних спондилоартритів (СнА) [3, 19]. Відомо, що найпоширенішою патологією серед осіб з АС є серцево-судинна (81 \%), котра і $є$ основною причиною смертності даної когорти пацієнтів, що, в свою чергу, становить в 1,5 раза вище популяційного рівня [6].

У даний час підтверджений чіткий взаємозв'язок між наявністю хронічного запального процесу та розвитком дисфрункції ендотелію. Дані про взаємозв'язок дисфункції ендотелію та артеріальної гіпертензії (АГ) досі залишаються суперечливими. 3 одного боку, не викликає сумнівів роль ендотелію в регуляції судинного тонусу, що дозволяє припустити його участь у патогенезі гіпертензії, з іншого боку, АГ, потенціюючи розвиток оксидантного стресу, є однією з ланок патогенезу самої дисфункції ендотелію [7, 10].

Складність оцінки впливу артеріальної гіпертензії на функцію ендотелію полягає також і в тому, що в більшості випадків пацієнти з ессенціальною гіпертензією мають ряд ССР, які самі по собі здатні впливати на стан ендотелію.

Мета роботи: встановити роль ендотеліальної диссункції в розвитку артеріальної гіпертензії у хворих на анкілозивний спондилоартрит.

(с) С.І. Сміян, Б.О. Кошак, А.В. Білуха, Д.О. Кошак, 2018
Матеріали і методи. У дослідженні взяли участь 110 пацієнтів. Критеріями включення в дослідження були: достовірний, відповідно до модиорікованих Нью-Йоркських критеріїв [2], діагноз АС та аксіального і периферійного спондилоартриту $[11,13]$, інфрормована згода пацієнта на участь в дослідженні, вік понад 50 років, наявність псоріазу, хвороби Крона, неспецифічного виразкового коліту, ішемічної хвороби серця, периферійного атеросклерозу, клінічно значущих вад серця (уроджених або набутих), недостатності кровообігу будь-якого генезу, цукрового діабету, тяжкого ураження печінки (активного гепатиту, цирозу), нирок (амілоїдозу чи іншої патології з розвитком хронічної ниркової недостатності), інших хронічних захворювань у фразі загострення (виразкової хвороби, холециститу, пієлонефриту тощо).

Всім пацієнтам, які погодилися взяти участь у дослідженні, проводили загальноклінічне стандартне обстеження (загальний аналіз крові, загальний аналіз сечі, ЕКГ, рентгенографрію та МРТ крижово-клубових зчленувань), біохімічний аналіз крові з ліпідограмою та визначенням гострофразових показників, виявлення HLA B-27, контроль АТ. Клінічну активність недуги визначали за допомогою індексу активності захворювання ASDAS, фрункціонального індексу BASFI, метрологічного індексу BASMI [2, 5, 13].

Діагноз АГ верифріковано згідно з рекомендаціями ESC/ESH від 2018 р. До моменту включення 
в дослідження всі пацієнти отримували базисну антигіпертензивну терапію із застосуванням інгібіторів ангіотензинперетворювального фрерменту (іАПФ) (8 хворих (36,4 \%)), блокаторів $\beta$-адренорецепторів (14 хворих (63,6 \%)) із комбінованим включенням діуретиків (6 хворих $(27,3 \%))$, що не змінювалась протягом усього дослідження.

3 метою оцінки стану ендотелію було проведено оцінку ендотелійзалежної вазодилатації у відповідь на реактивну гіперемію (потокозалежна вазодилатація) за методом, який вперше описав D. Celermajer [4], з використанням ультразвукового комплексу, оснащеного лінійним датчиком. Виконували проби з реактивною гіперемією (ендотелійзалежний стимул) і нітрогліцерином (ендотелійнезалежний стимул) [8]. Ендотелійзалежну вазодилатацію (ЕЗВД) розраховували за фрормулою ЕЗВД=(d60-d0)×100 \%/d0, де d60 - діаметр плечової артерії через 60 с після відновлення кровообігу, d0 - вихідний діаметр плечової артеpіï. Ендотелійнезалежну вазодилатацію (ЕНВД) на тлі приймання нітрогліцерину розраховували за фрормулою: ЕНВД=(d5- d0)×100 \%/d0, де d5 - діаметр плечової артерії через 5 хв після приймання нітрогліцерину, d0 - вихідний діаметр плечової артерії. Для оцінки співвідношення між ЕНВД і ЕЗВД розраховували індекс реактивності (IP) плечової артерії за фрормулою: IP=ЕНВД/ ЕЗВД.

Статистичну обробку отриманих результатів проводили відомими методами варіаційної статистики у пакеті прикладних програм SPSS22 (CSPSS Inc.).

Результати дослідження та їх обговорення. Серед пацієнтів, які взяли участь у дослідженні,

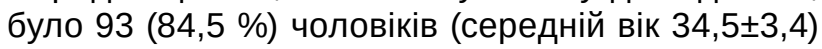
та $17(15,5 \%)$ жінок (середній вік 38,2ะ4,1) 3 тривалістю недуги в середньому $(12,2 \pm 3,7)$ року, причому I ступінь активності був констатований у 24 хворих (21,8 \%), II - у 47 (42,7\%), III - 39 (35,5 \%) відповідно (за ASDAS). Результати дослідження фрункції ендотелію у пацієнтів з АС показали, що знижену ЕЗВД (менше $10 \%$ ), що є ознакою дисфункції ендотелію, значно частіше спостерігали серед хворих з АС, і її виявлено у 79 обстежуваних (71,9\%), нормальну ЕЗВД (більше $10 \%)$ виявлено лише у 31 хворого (28,1 \%) (рис. 1).

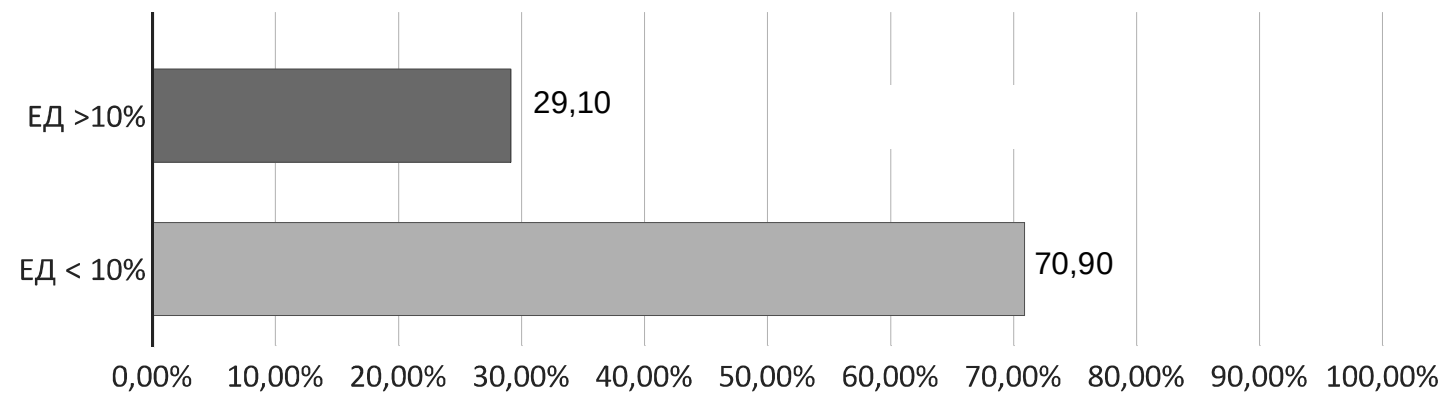

$$
\text { ЕД }<10 \% \quad \square \text { ЕД }>10 \%
$$

Puc. 1. Розподіл пацієнтів за вазорегулювальною здатністю ендотелію.

Встановлено, що практично кожен третій пацієнт (n=42 (38,2 \%)) хворів на АГ, причому частота її реєстрації перевищує поширеність в загальній популяції (в міській - 29,3 \%, у сільській розповсюдженість АГ - 36,3 \%) [13]. Варто відзначити, що у всіх хворих на АГ (100\%), ЕЗВД становила менше $10 \%$.

І стадія АГ встановлена у 15 (13,6 \%) хворих, II стадія - у 27 (24,6 \%), 1 ступінь АГ у 18 (16,4 \%) пацієнтів, 2 ступінь - у 24 (21,8 \%) хворих. Показник САТ у середньому становив $(145,78 \pm 17,3)$ мм рт. ст., ДАТ - $(85,47 \pm 8,77)$ мм рт. ст.

3 метою пошуку ключових чинників ризику розвитку АГ (n=42) було проаналізовано різноманітні серцево-судинні фрактори ризику та їх поширеність серед обстежених хворих (табл. 1).

Отримані дані демонструють порушення фрункції ендотелію у 71,8 \% хворих. Потовщення комплексу інтима-медіа загальної сонної артерії >1 мм виявлено в 20,9 \% пацієнтів з АС. Висока частота куріння серед пацієнтів з АС може бути пояснена переважанням осіб чоловічої статі. Достатньо велика когорта обстежених демонструвала знижений рівень ЛПВщ і підвищений рівень лПНЩ за умов наявності хворих із гіперхолестеринемією в значно меншій кількості. Класичні ж фрактори ризику розвитку захворювань СС системи (надлишкова маса, куріння, сімейний анамнез розвитку захворювань) не перевищували поширеність таких же у загальній популяції.

3 метою систематизації чинників ризику АГ у хворих на АС було проаналізовано клініко-лабораторні характеристики пацієнтів та основні СС фактори ризику в пацієнтів залежно від наявності гіпертензії (табл. 2).

Проаналізувавши отримані дані, встановлено, що у хворих на АГ та без, не було виявлено 
Таблиця 1. Поширеність традиційних факторів серцево-судинного ризику серед пацієнтів 3 артеріальною гіпертензією

\begin{tabular}{|c|c|c|}
\hline Ознака & $\mathrm{n}$ & $\%$ \\
\hline ЕЗВД <10 \% & 79 & 71,8 \\
\hline TIM загальної сонної артерії >1 мм & 23 & 20,9 \\
\hline Куріння & 24 & 21,8 \\
\hline Гіперхолестеринемія (3X>5,2 ммоль/л) & 34 & 30,9 \\
\hline Знижений рівень ЛПВЩ (<1 ммоль/л для чоловіків та <1,2 ммоль/л для жінок) & 44 & 40,0 \\
\hline Підвищений рівень ЛПнЩ (>3,0 ммоль/л) & 51 & 46,4 \\
\hline Гіпертригліцеридемія (ТГ>1,7 ммоль/л) & 16 & 14,5 \\
\hline Надлишкова маса тіла (IMT>25 кг/м²) & 10 & 9,9 \\
\hline Сімейний анамнез раннього розвитку серцево-судинних захворювань & 15 & 13,6 \\
\hline
\end{tabular}

Таблиця 2. Клініко-лабораторна характеристика та основні серцево-судинні фактори ризику в пацієнтів залежно від наявності артеріальної гіпертензії

\begin{tabular}{|c|c|c|c|}
\hline Показник & $\begin{array}{l}\mathrm{A} \Gamma(-) \\
(n=68)\end{array}$ & $\begin{array}{l}\mathrm{A} \Gamma(+) \\
(\mathrm{n}=42)\end{array}$ & $\mathrm{p}$ \\
\hline Середній вік, роки & $33,7 \pm 1,4$ & $34,2 \pm 1,8$ & $p=0,65$ \\
\hline Тривалість захворювання, роки & $7,17 \pm 1,1$ & $14,2 \pm 2,3$ & $p<0,001$ \\
\hline Вік початку захворювання, роки & $29,8 \pm 5,4$ & $23,5 \pm 4,8$ & $p=0,1$ \\
\hline Індекс маси тіла, кг/м & $22,4 \pm 3,5$ & $22,9 \pm 3,1$ & $p=0,1$ \\
\hline Куріння (абс., \%) & $21(30,8)$ & $13(30,9)$ & \\
\hline Анамнез куріння, пачко-роки & $8,2 \pm 2,1$ & $9,4 \pm 1,9$ & $p=0,4$ \\
\hline $\begin{array}{l}\text { Сімейний анамнез раннього розвитку серцево- } \\
\text { судинних захворювань (абс., \%) }\end{array}$ & $9(13,2)$ & $6(14,3)$ & \\
\hline ЗХ, ммоль/л & $4,15 \pm 0,41$ & $5,51 \pm 0,29$ & $p<0,001$ \\
\hline ЛПВЩ, ммоль/л & $1,21 \pm 0,13$ & $0,91 \pm 0,08$ & $p<0,001$ \\
\hline ЛПНЩ, ммоль/л & $2,42 \pm 0,14$ & $3,31 \pm 0,35$ & $p<0,001$ \\
\hline ТГ, ммоль/л & $1,18 \pm 0,24$ & $1,31 \pm 0,38$ & $p=0,4$ \\
\hline $\mathrm{IA}$ & $2,44 \pm 0,23$ & $5,05 \pm 0,19$ & $p<0,001$ \\
\hline ТІМ сонних артерій, мм & $0,77 \pm 0,09$ & $0,94 \pm 0,07$ & $p<0,001$ \\
\hline ЕЗВД, \% & $9,25 \pm 1,04$ & $7,11 \pm 0,78$ & $p<0,001$ \\
\hline BASDAI, cM & $5,12 \pm 1,74$ & $6,72 \pm 1,85$ & $p=0,4$ \\
\hline BASFI, CM & $5,15 \pm 0,41$ & $7,42 \pm 0,52$ & $p=0,018$ \\
\hline С-реактивний білок, мг/л & $7,75 \pm 0,58$ & $15,24 \pm 0,75$ & $p<0,001$ \\
\hline ШОЕ, мм/год & $14,32 \pm 1,24$ & $28,81 \pm 4,46$ & $p<0,001$ \\
\hline
\end{tabular}

відмінностей за класичними фракторами ризику, окрім дисліпідемій та TIM, порівняно з пацієнтами без АГ. Поряд із тим, виявлено суттєві відмінності за показниками активності захворювання (СРБ, ШОЕ, BASDAI) та фрункціонального статусу (BASFI), аналогічні таким, що були виявлені при аналізі порушеної та нормальної ЕЗВД.

\section{Висновки}

Можна припустити, що саме дисорункція ендотелію, котра виникає на фроні системного запального синдрому, що було неодноразово продемонстровано на багатьох клінічних моделях, зокрема ревматоїдному артриті [12], ймовірно, є основною причиною розвитку АГ у хворих на $\mathrm{AC}$, адже відмінностей за іншими класичними фракторами ССР, окрім дисліпідемій, виявлено не було.

Перспективи подальших досліджень полягають у подальшій розробці методів оптимізації лікування та діагностики проявів дисфункції ендотелію у хворих на АС з метою запобігання розвитку серцево-судинних захворювань. 


\section{Список літератури}

1. Hydrogen sulfide and endothelial dysfunction: relationship with nitric oxide / Z. Altaany, F. Moccia, L. Munaron [et al.] // Curr. Med. Chem. - 2014. - Vol. 21 (32). - P. 3646-3661.

2. Braun J. Ankylosing spondylitis / J. Braun // Lancet. - 2007. - Vol. 369. - P. 1379-1390.

3. Busse R. Endothelium-derived bradykinin: implications for angiotensin-converting enzyme-inhibitor therapy / R. Busse,

I. Fleming, M. Hecker // J. Cardiovasc. Pharmacol. - 1993. - Vol. 22. - P. 31-36.

4. Celermajer D. S. Non-invasive detection of endothelial dysfunction in children and adults at risk of atherosclerosis $/$

D. S. Celermajer, K. E. Sorensen,V. M. Gooch [et al.] // Lancet. - 1992. - Vol. 340. - P. 1111-1115.

5. Chen H. A. Clinical, functional, and radiographic differences among juvenile-onset, adult-onset, and late-onset ankylosing spondylitis / H. A. Chen, C. H. Chen, H. T. Liao // J. Rheumatol. - 2012. - Vol. 39. - P. 3-8.

6. Donald J. A. The evolution of nitric oxide signalling in vertebrate blood vessels // J. A. Donald, L. G. Forgan, M. S. Cameron // J. Comp. Physiol. B. - 2015. - Vol. 185 (2). - P. 153-171.

7. Arterial stiffness is not increased in patients with short duration rheumatoid arthritis and ankylosing spondylitis / A. J. Dzieża-Grudnik, Sulicka, M. Strach [et al.] // Blood Press. - 2017. - Vol. 26 (2). - P 115-121.

8. Heeneman S. Cardiovascular risks in spondyloarthritides / S. Heeneman, M. J. Daemen // Curr. Opin. Rheumatol. 2017. - Vol. 19. - P. 358-362.

9. Korkmaz $H$. Early effects of treatment with nebivolol and quinapril on endothelial function in patients with hypertension / I. Karaca, M. Koç // Endothelium. - 2008. - Vol. 15 (3). - P. 149-155.

10. Enhancing vascular relaxing effects of nitric oxide-donor ruthenium complexes / M. Paulo, T. M. Banin, F. A. de Andrade, L. M. Bendhack // Future Med. Chem. - 2014. - Vol. 6 (7). - P. 825-838.

11. Smith J. A. Update on ankylosing spondylitis: current concepts in pathogenesis / J. A. Smith // Curr. Allergy Asthma Rep. - 2015. - Vol. 15 (1). - P. 489.

12. Sokka T. Mortality in rheumatoid arthritis: 2008 update / T. Sokka, B. Abelson, T. Pincus // Clin. Exp. Rheumatol. - 2008. Vol. 26 (51). - P. 356-361.

13. 2016 update of the ASAS-EULAR management recommendations for axial spondyloarthritis / D. Van der Heijde, S. Ramiro, R. Landewé [et al.] // Ann. Rheum. Dis. - 2017. - Vol. 76 (6). - P. 978-991.

\section{Referens}

1. Altaany, Z., Moccia, F. \& Munaron L. (2014). Hydrogen sulfide and endothelial dysfunction: relationship with nitric oxide. Curr. Med. Chem., 21 (32), 3646-3661.

2. Braun, J. (2007). Ankylosing spondylitis. Lancet, 369, 1379-1390.

3. Busse, R., Fleming, I., \& Hecker, M. (1993). Endothelium-derived bradykinin: implications for angiotensin-converting enzyme-inhibitor therapy. J. Cardiovasc. Pharmacol., 22, 31-36.

4. Celermajer, D.S., Sorensen, K.E., Gooch, V.M. (1992). Non-invasive detection of endothelial dysfunction in children and adults at risk of atherosclerosis. Lancet, 340, 1111-1115.

5. Chen, H.A., Chen, C.H., \& Liao, H.T. (2012). Clinical, functional, and radiographic differences among juvenile-onset, adult-onset, and late-onset ankylosing spondylitis. J. Rheumatol., 39, 3-8.

6. Donald, J.A., Forgan, L.G., \& Cameron, M.S. (2015). The evolution of nitric oxide signalling in vertebrate blood vessels. J. Comp. Physiol. B., 185 (2), 153-171.

7. Dzieża-Grudnik, A., Sulicka, J., \& Strach, M. (2017). Arterial stiffness is not increased in patients with short duration rheumatoid arthritis and ankylosing spondylitis. Blood Press., 26 (2), 115-121.

8. Heeneman, S., \& Daemen M.J. (2017). Cardiovascular risks in spondyloarthritides. Curr. Opin. Rheumatol., 19, $358-362$. 9. Korkmaz, H., \& Koç, M. (2008). Early effects of treatment with nebivolol and quinapril on endothelial function in patients with hypertension. Endothelium, 15 (3), 149-155.

10. Paulo, M., Banin, T.M., de Andrade, F.A., \& Bendhack, L.M. (2014). Enhancing vascular relaxing effects of nitric oxidedonor ruthenium complexes. Future Med. Chem., 6 (7), 825-838.

11. Smith, J. A. (2015). Update on ankylosing spondylitis: current concepts in pathogenesis. Curr. Allergy Asthma Rep., 15 (1), 489.

12. Sokka, T., Abelson, B., \& Pincus, T. (2008). Mortality in rheumatoid arthritis: 2008 update. Clin Exp Rheumatol., 26 (51), 356-361.

13. Van der Heijde, D., Ramiro, S., \& Landewé, R. (2017). 2016 update of the ASAS -EULAR management recommendations for axial spondyloarthritis. Ann. Rheum. Dis., 76 (6), 978-991.

\section{РОЛЬ ЭНДОТЕЛИАЛЬНОЙ ДИСФУНКЦИИ В РАЗВИТИИ АРТЕРИАЛЬНОЙ ГИПЕРТЕНЗИИ У БОЛЬНЫХ АНКИЛОЗИРУЮЩИМ СПОНДИЛОАРТРИТОМ}

С.И. Смиян, Б.А. Кошак, А.В. Билуха, Д.А. Кошак

ГВУЗ «Тернопольский государственный медицинский университет имени И.Я. Горбачевского МЗ Украины», г. Тернополь, Украина

Цель: установить роль эндотелиальной диссункции в развитии артериальной гипертензии у больных анкилозирующим спондилоартритом.

Материалы и методы. Обследовано 110 пациентов с анкилозирующим спондилоартритом, которым проводили оценку функции эндотелия. К моменту включения в исследование все пациенты получали базисную антигипертензивную терапию, которая не изменялась в ходе исследования. 
Результаты. Установлено, что практически каждый третий пациент болел артериальной гипертензией, нарушение фрункции эндотелия обнаружено в 71,8 \% больных. Достаточно большая когорта обследованных демонстрировала пониженный уровень ЛПВП и повышенный уровень ЛПнП. Вместе с тем, выявлены существенные различия по показателям активности заболевания (СРБ, СОЭ, BASDAI) и фрункционального статуса (BASFI) у лиц с артериальной гипертензией и без.

Выводы. Можно предположить, что именно дисфункция эндотелия, которая возникает на фоне системного воспалительного синдрома, вероятно, является основной причиной развития артериальной гипертензии у пациентов с анкилозирующим спондилоартритом, ведь различий по другим классическим фракторам ССР, кроме дислипидемий, обнаружено не было.

КЛЮЧЕВЫЕ СЛОВА: анкилозирующий спондилоартрит; артериальная гипертензия; эндотелиальная дисорункция.

\section{THE ROLE OF ENDOTHELIAL DYSFUNCTION IN THE DEVELOPMENT OF ARTERIAL HYPERTENSION IN PATIENTS WITH ANKYLOSING SPONDYLARTHRITIS \\ S.I. Smiyan, B.O. Koshak, A.V. Bilukha, D.O. Koshak \\ I. Horbachevsky Ternopil State Medical University}

Purpose: to establish the role of endothelial dysfunction in the development of arterial hypertension in patients with ankylosing spondylarthritis.

Materials and Methods. A total of 110 patients with AS were examined with evaluation endothelium-dependent vasodilation (EDVD). All patients received antihypertensive therapy which did not change throughout all study.

Results. It was found that every third patient suffered from hypertension, endothelial function disorders were detected in $71.8 \%$ of patients. A large cohort of patients showed low levels of HDL and elevated levels of LDL.

At the same time, significant differences in disease activity and functional status were found in the group with hypertension.

Conclusions. We must assume that endothelial dysfunction, which occurs on the background of systemic inflammatory syndrome, is probably the main reason for the development of hypertension in patients with AS.

KEY WORDS: ankylosing spondylitis; arterial hypertension; endothelial dysfunction.

Рукопис надійшов до редакції 27.06.2018 p.

\section{Відомості про авторів:}

Сміян Світлана Іванівна - заслужений діяч науки та техніки України, доктор медичних наук, професор, завідувач кафредри внутрішньої медицини № 2 ДВНЗ «Тернопільський державний медичний університет імені І. Я. Горбачевського МОЗ України».

Кошак Богдан Олександрович - асистент кафедри фрунціональної та лабораторної діагностики ДВНЗ «Тернопільський державний медичний університет імені І. Я. Горбачевського МОЗ України».

Білуха Анастасія Вікторівна - лікар-інтерн Тернопільської університетської лікарні.

Кошак Денис Олександрович - старший лаборант кафредри травматології та ортопедії з військово-польовою хірургією ДВНЗ «Тернопільський державний медичний університет імені І. Я. Горбачевського МОЗ України». 